\title{
AN ANALYSIS ON THE INCOMES AND EXPENDITURES OF TURKISH FOOTBALL FEDERATION AND THE INCOMES OF THE FOUR MAJOR CLUBS
}

\author{
Lale ORTA ${ }^{1}$, Murat KORKMAZ ${ }^{2}$ \\ ${ }^{1}$ Okan University, Graduate School of Applied Sciences, Department of Sport \\ Management ${ }^{2}$ Güven Group Inc. Finance Management
}

\begin{abstract}
In our study, the financial structure of Turkish Football Federation (TFF) and the clubs called four majors in Turkish public was examined over their income and expenditure items. Certain income and expenditure items of 2008-2009 and 2009-2010 football seasons were used as data for TFF. Firstly, it was focused on whether there was a change between the average incomes of 2008-2009 and 2009-2010 seasons. A normality test was made for income items, and Wilcoxon test was applied due to the fact that data did not demonstrate a normal distribution. As a result of the test, it was found that there was not a meaningful difference between the average incomes of 2008-2009 and 2009-2010 seasons. On the other side of the study, it was examined whether there was a change between TFF's average expenditures of 2008-2009 and 2009-2010 seasons. The same normality test was also made for expenditure items, and paired $t$ test was applied due to the fact that data demonstrated a normal distribution. As a result of the test, it was found that there was not a meaningful difference between the average expenditures of 2008-2009 and 2009-2010 seasons. In the final part of the study, it was examined whether there was a change between the average incomes of the four major Turkish clubs in the 2010-2011 football season. Several income items were used as data for that purpose. A normality test was applied for the income items, and it was found that data did not demonstrate a normal distribution. In that case, Kruskal-Wallis test was applied to determine whether there was a change between the average incomes of the four major Turkish clubs in the 2010-2011 football season, and a graphical demonstration was presented for income levels.
\end{abstract}

Key Words: Football, Football Federation, Team, Income, Expenditure

This paper was sent as presentation to the 12th Sport Sciences Congress that will be held in Denizli on 12-14 December, 2012.

\section{INTRODUCTION AND OBJECTIVE}


With its rules, economy, culture, national and international cups, visual and aesthetical pleasure, struggle, transfers and excitement, football achieve to bring together tens of thousands to stadiums and billions of people on radio and television (Orta, 2008). Football is also considered as a sociological phenomenon for its feature of reflecting the community (Akaya, 2008).

As in many world countries, the most popular sports branch is football in Turkey, as well. Football activities carried out by sports clubs that are usually organized as associations creates a great economy in Turkey as in other countries (Devecioğlu, S., Çoban, B. 2003). With the fast moneratization and commercialization of football, an economy reaching hundreds of billion dollars emerged. Distribution and sharing of the incomes from football also determines competitive powers of the clubs (Akşar, 2010). The universal and unbalanced development dynamics of football make its local problems universal (Akşar and Merih, 2006). Prominent clubs of commercializing and ever industrializing Europe seek to have a structuring for the purpose of outpointing its competitors in economic matters and to increase their incomes (Akşar, 2008a).

While football evolves from being a sport into industry, sports clubs are also seen as an economic organization. This evolvement and development process is seen in the marketing of football byproducts, football-media relations as well as in the profile of fans and football stars (Inan, 2007). Today, football is subject to free market norms and rules as all commercial sectors around the world. A sports club that cannot perform the Financial Fair Play rules both in management and economic way will have difficulty in surviving within the football world. In this context, sports clubs are liable to conduct modern methods of entrepreneurship that will bring success and fulfill the requirements of organizational management (Katırcı\&Uztuğ, 2009).

Turkish football has experienced remarkable improvements in sports success with the autonomous management model, and substantial improvements were achieved through legal regulations in the administrative structure of football (Devecioğlu, 2003). In order to have a place in this evolving football sector, sports clubs should catch up with economic structuring and have a structure to follow closely financial movements (Devecioğlu\&Çoban, 2003).

The greatest source of income for football clubs in Turkey are live broadcast incomes supplied from broadcasting agency. Considering that Turkish clubs are not satisfactory enough from other income items, the importance of broadcast income from the "pool bidding" becomes more clear (Arık, 2008). Since football is now a product bringing huge amounts of income, the issue of broadcasting matches creates a problem for our country as well as other countries in the world (Demir, 1998). Ticket prices, combined card prices, merchandising and the fees of football players all determine the balance of supply-demand, which is one of the fundamental principles of football economy (Doğru, 2010).

Spor Toto Super League follows, in terms of incomes, the five major European league (England, Germany, Spain, Italy, France), followed by Russia and the Netherlands. The Russia 
League gaining an income of 614 million Euros was followed by the Super League with an income of 515 million Euros in 2010-2011 season (Deloitte, 2012).

Turkish Football Federation (TFF) is the agency that has all the legal and managerial power for the management, inspection, organization and arrangement of football in our country (Akşar, 2008b). Subject to the Law on Turkish Football Federation Foundation and Tasks no. 5894, the following items generate the incomes:

a) $15 \%$ of the name right granted to clubs for football mutual and fixed odds betting.

b) Application fees and punishments.

c) $10 \%$ of the incomes of the clubs gained from competition broadcastings via television, radio, internet and all kinds of devices etc. as well as all contracts they will sign with media organs.

ç) Incomes gained from sponsorship contracts signed by TFF

d) Net amount after deductions of the incomes gained from official and private national competitions, and incomes gained from their broadcasting via television, radio, internet and all kinds of devices etc.

e) Incomes gained from registration, visa, transfer, dues, and football players affiliated to TFF and such incomes from the clubs.

f) Property incomes, incomes gained from the transfer, assignment, sale and rent of property values.

g) Incomes gained from all kinds of incentives and corporations to be founded or partnered by TFF.

g) Interest incomes.

h) Grants and benefits.

1) Other incomes.

As per Article 9 of the Law no. 5894, below are the expenditures of TFF:

According to the five year-budget basis of TFF, it prepares its own budget and incurs all necessary costs and expenditures within the framework of TFF Status in order to perform the tasks assigned to it under the Law.

Financial situation and profit/loss calculations are inspected every year by an independent audit institution having experience in international audit in sports sector, and audit reports 
4 I P a g e International Journal of Management Sciences and Business Research, 2012, Vol. 1, Issue 7. (ISSN: 2226-8235)

are declared publicly following tested by the General Council. All other incomes of TFF are exempted from all kinds of taxes, duties and charges. (TFF Law No. 5894, 2009)

In our study, it will be examined whether there was a change between TFF's average incomes and expenditures of 2008-2009 and 2009-2010 football seasons. Also, in the final part of the study, it will be analyzed whether there was a change between the average incomes of the four major Turkish clubs in the 2010-2011 football season.

\section{METHODOLOGY}

In this study, average comparison tests were applied to determine the financial structure. Thus, firstly, it was analyzed whether data demonstrates a normal distribution or not. Appropriate average comparison test will be selected according to the suitability for the normal distribution of data. Parametric tests will be applied for the data demonstrating a normal distribution, and nonparametric tests for the data not demonstrating a normal distribution.

Certain income and expenditure items of TFF in 2008-2009 and 2009-2010 football seasons were used as data. A normality test was made for income items, and Wilcoxon test was applied due to the fact that data did not demonstrate a normal distribution. On the other side of the study, it was examined whether there was a change between TFF's average expenditures of 2008-2009 and 2009-2010 seasons. The same normality test was also made for expenditure items, and paired t-test was applied due to the fact that data demonstrated a normal distribution. The main reason for using paired t-test was to make measurement on the same variables and make assessment on two groups. In the final part of the study, averages of several income items of the four major Turkish clubs in the 2010-2011 football season were used as data. A normality test was applied for the income items of the four major Turkish clubs, and it was found that data did not demonstrate a normal distribution. In that case, Kruskal-Wallis test was applied to examine differences between the averages.

\section{FINDINGS}

While Table. 1 shows the income items for TFF in 2008-2009 and 2009-2010 football seasons, Table. 2 shows the expenditure items (TFF; 2009, 2010a, 2010b).

Table. 1: TFF Incomes Between 1 June 2008 - 31 May 2010

\begin{tabular}{l|l|l}
\hline Income Items & $\begin{array}{l}\mathbf{1} \text { June 2008 - } \\
\mathbf{3 1} \text { May 2009 }\end{array}$ & $\begin{array}{l}\mathbf{1} \text { June 2009 - } \\
\mathbf{3 1} \text { May 2010 }\end{array}$ \\
\hline Education Incomes & 1.801 .455 & $\mathbf{2 . 7 3 7 . 6 1 1}$ \\
\hline National Team Incomes & 18.112 .973 & 6.207 .618 \\
\hline Professional Football Incomes & 83.706 .366 & 74.584 .963 \\
\hline Amateur Football Incomes & 7.540 .488 & 9.230 .523 \\
\hline UEFA and FIFA Incomes & 6.593 .803 & 6.656 .681 \\
\hline
\end{tabular}

AN ANALYSIS ON THE INCOMES AND EXPENDITURES OF TURKISHYOOTBALL FEDERATION AND THE INCOMES OF THE FOUR MAJOR CLUBS 
5 | P a g e International Journal of Management Sciences and Business Research, 2012, Vol. 1, Issue 7. (ISSN: 2226-8235)

\begin{tabular}{l|l|l}
\hline Sponsorship Incomes & 28.049 .499 & 41.916 .075 \\
\hline Current Incomes & 12.900 .701 & 4.890 .331 \\
\hline Other Extraordinary Incomes and Profits & 0 & 50.250 \\
\hline & & \\
\hline Total of Incomes & $\mathbf{1 5 8 . 7 0 5 . 2 8 5}$ & $\mathbf{1 4 6 . 2 7 4 . 0 5 2}$ \\
\hline
\end{tabular}

Table. 2: TFF Expenditures Between 1 June 2008 - 31 May 2010

\begin{tabular}{l|l|l}
\hline Expenditure Items & $\begin{array}{l}\mathbf{1} \text { June 2008- } \\
\mathbf{3 1} \text { May 2009 }\end{array}$ & $\begin{array}{l}\mathbf{1} \text { June 2009- } \\
\mathbf{3 1 ~ M a y ~ 2 0 1 0}\end{array}$ \\
\hline Education Expenditures & 9.160 .834 & 8.436 .579 \\
\hline National Team Expenditures & 46.265 .441 & 34.003 .411 \\
\hline Professional Football Expenditures & 26.973 .957 & 48.400 .325 \\
\hline Amateur Football Expenditures, & 15.547 .838 & 21.529 .730 \\
\hline UEFA and FIFA Expenditures & 5.201 .018 & 1.383 .947 \\
\hline Expenditures Set Forth in the Law & 11.776 .313 & 14.090 .969 \\
\hline R\&D and Project Expenditures & 2.641 .741 & 11.444 .307 \\
\hline Current Expenditures & 34.404 .280 & 31.648 .507 \\
\hline Other Ordinary Expenditures & 1.294 .655 & 1.827 .077 \\
\hline Total of Expenditures & & \\
\hline & $\mathbf{1 5 3 . 2 6 6 . 0 7 7}$ & $\mathbf{1 7 2 . 7 6 4 . 8 5 2}$ \\
\hline
\end{tabular}

Table. 3: Beşiktaş, Fenerbahçe, Galatasaray and Trabzonspor Incomes in 2010-2011

\begin{tabular}{|l|l|l|l|l|}
\hline Income Items & Galatasaray & Fenerbahçe & Beşiktaş & Trabzonspor \\
\hline Match Day Incomes & 17.333 .714 & 41.783 .280 & 22.103 .734 & 7.093 .481 \\
\hline Broadcast Incomes & 43.426 .159 & 41.214 .684 & 55.692 .265 & 83.964 .647 \\
\hline Commercial Incomes & 69.774 .881 & 98.239 .719 & 41.296 .349 & 14.319 .251 \\
\hline Financial Incomes & & & & \\
\hline
\end{tabular}

\section{ANALYSIS FOR TFF INCOME ITEMS}

It will be examined whether there was a change between TFF's incomes of 2008-2009 and 2009-2010 seasons. For that purpose, following income items will be used as observation values:

- Education Incomes

- National Team Incomes

- Professional Football Incomes

- Amateur Football Incomes

- UEFA and FIFA Incomes

AN ANALYSIS ON THE INCOMES AND EXPENDITURES OF TURKISHGFOOTBALL FEDERATION AND THE INCOMES OF THE FOUR MAJOR CLUBS 
6 I P a g e International Journal of Management Sciences and Business Research, 2012, Vol. 1, Issue 7. (ISSN:

- Sponsorship Incomes

- Current Incomes

Firstly, it will be analyzed whether TFF's income items of 2008-2009 and 2009-2010 seasons demonstrate a normal distribution or not.

Tests of Normality
\begin{tabular}{|l|l|l|l|l|l|l|}
\hline \multicolumn{3}{|l|}{ Kolmogorov-Smirnov ${ }^{\mathrm{a}}$} & \multicolumn{3}{l|}{ Shapiro-Wilk } \\
\cline { 2 - 8 } & Statistic & df & Sig. & Statistic & df & Sig. \\
\hline Incomes 2008-2009 &, 282 & 7 &, 099 &, 727 & 7 &, 007 \\
Incomes 2009-2010 &, 380 & 7 &, 003 &, 713 & 7 &, 005 \\
\hline
\end{tabular}

a. Lilliefors Significance Correction

Normality test results can be seen in the Table above. The number of observations is lower than 50 for the income items of 2008-2009 and 2009-2010 seasons, and therefore, ShapiroWilk test is applied. According to test results, it was found that within the country, meaningfulness value for the incomes of 2008-2009 season is 0,007<0,05, and for the incomes of $2009-2010$ is $0,005<0,05$. So, it is the case that both variables do not demonstrate a normal distribution at a significance level of $5 \%$.

\section{WILCOXON TEST}

Incomes of 2008-2009 and 2009-2010 seasons do not demonstrate a normal distribution. Therefore, Wilcoxon test will be applied to test whether there is a difference between TFF's incomes of 2008-2009 and 2009-2010 seasons. The test is used as a nonparametric alternative method to the dependent sampling t-test.

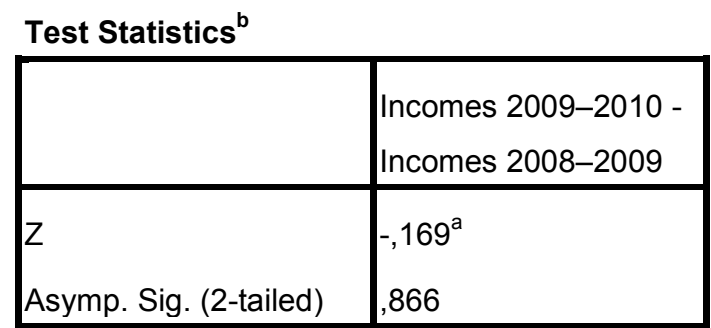
a. Based on positive ranks.
b. Wilcoxon Signed Ranks Test 
7 I P a g e International Journal of Management Sciences and Business Research, 2012, Vol. 1, Issue 7. (ISSN:

Wilcoxon test result can be seen in the Table above. According to it, $Z$ score obtained got the test statistics was calculated as $-0,169$, and the meaningfulness value as $0,866>0,05$.

According to the meaningfulness value, no meaningful difference was found between the average incomes of 2008-2009 and 2009-2010 seasons at a significance level of 5\%.

Ranks

\begin{tabular}{|c|c|c|c|c|}
\hline & & $\mathrm{N}$ & Mean Rank & Sum of Ranks \\
\hline \multirow{4}{*}{$\begin{array}{l}\text { Incomes 2009-2010 Incomes } \\
2008-2009\end{array}$} & Negative Ranks & $3^{a}$ & 5,00 & 15.00 \\
\hline & Positive Ranks & $4^{b}$ & 3,25 & 13,00 \\
\hline & Ties & $0^{c}$ & & \\
\hline & Total & 7 & & \\
\hline
\end{tabular}

a. Incomes $2009-2010<$ Incomes 2008-2009

b. Incomes 2009-2010 > Incomes 2008-2009

c. Incomes $2009-2010=$ Incomes 2008-2009

The order totals and order averages of the income items of 2008-2009 and 2009-2010 seasons can be seen in the Table above. According to it, when we look at the order averages, it was calculated as 5 for 2008-2009 season and 3,25 for 2009-2010 season. In conclusion, this difference is not statistically meaningful.

According to those results, no meaningful difference was found between the average incomes of 2008-2009 and 2009-2010 seasons.

\section{ANALYSIS FOR TFF EXPENDITURE ITEMS}

It will be examined whether there was a change between TFF's expenditures of 2008-2009 and 2009-2010 seasons. For that purpose, following expenditure items will be used as observation values:

- Education Expenditures

- National Team Expenditures

- Professional Football Expenditures

- Amateur Football Expenditures

- UEFA and FIFA Expenditures

- Expenditures set forth in the Law

- R\&D and project Expenditures

- Other Ordinary Expenditures 
8 I P a g e International Journal of Management Sciences and Business Research, 2012, Vol. 1, Issue 7. (ISSN:

Firstly, it will be analyzed whether the expenditure items of 2008-2009 and 2009-2010 seasons demonstrate a normal distribution or not.

Tests of Normality

\begin{tabular}{|l|l|l|l|l|l|l|}
\hline \multicolumn{4}{|c|}{ Kolmogorov-Smirnov ${ }^{a}$} & \multicolumn{2}{l|}{ Shapiro-Wilk } \\
\cline { 2 - 7 } & Statistic & df & Sig. & Statistic & df & Sig. \\
\hline Expenditures 2008-2009 &, 214 & 8 &, $200^{*}$ &, 913 & 8 &, 374 \\
Expenditures 2009-2010 &, 179 & 8 &, $200^{*}$ &, 957 & 8 &, 777 \\
\hline
\end{tabular}

a. Lilliefors Significance Correction

*. This is a lower bound of the true significance.

Normality test results can be seen in the Table above. The number of observations is lower than 50 for the expenditure items of 2008-2009 and 2009-2010 seasons, and therefore, Shapiro-Wilk test is applied. According to test results, it was found that within the country, meaningfulness value for the expenditures of 2008-2009 season is 0,374>0,05, and for the expenditures of $2009-2010$ is $0,777<0,05$. So, it is the case that both variables demonstrate a normal distribution at a significance level of $5 \%$.

\section{DEPENDENT SAMPLING T-TEST}

Expenditures of 2008-2009 and 2009-2010 seasons demonstrate a normal distribution. Therefore, the dependent sampling t-test will be applied to test whether there is a difference between TFF's expenditures of 2008-2009 and 2009-2010 seasons.

Paired Samples Statistics

\begin{tabular}{|ll|l|l|l|l|}
\hline & Mean & N & Std. Deviation & Std. Error Mean \\
\hline Pair 1 & $\begin{array}{llll}\text { Expenditures 2008-2009 } \\
\text { Expenditures 2009-2010 }\end{array}$ & $1.90 \mathrm{E} 7$ & 8 & $1.541 \mathrm{E} 7$ & $5.450 \mathrm{E} 6$ \\
& $2.14 \mathrm{E} 7$ & 8 & $1.565 \mathrm{E} 7$ & $5.533 \mathrm{E} 6$ \\
\hline
\end{tabular}

Error values for average and standard deviation from descriptive statistics are presented in the Table above. 
9 I P a g e International Journal of Management Sciences and Business Research, 2012, Vol. 1, Issue 7. (ISSN:

\begin{tabular}{|c|c|c|c|c|c|c|c|}
\hline & \multicolumn{4}{|c|}{ Paired Differences } & \multirow[b]{3}{*}{$\mathrm{t}$} & \multirow[b]{3}{*}{ df } & \multirow[b]{3}{*}{$\begin{array}{l}\text { Sig. (2- } \\
\text { tailed) }\end{array}$} \\
\hline & \multirow[b]{2}{*}{ Mean } & \multirow[b]{2}{*}{ Std. Deviation } & \multicolumn{2}{|c|}{$\begin{array}{l}95 \% \text { Confidence Interval of } \\
\text { the Difference }\end{array}$} & & & \\
\hline & & & Lower & Upper & & & \\
\hline $\begin{array}{l}\text { Expenditures 2008- } \\
2009 \text { - Expenditures } \\
2009-2010\end{array}$ & $-2.371 \mathrm{E}+06$ & $1.004 \mathrm{E}+07$ & $-1.077 \mathrm{E}+07$ & $6.024 \mathrm{E}+06$ & -.668 & 7 & .526 \\
\hline
\end{tabular}

Dependent sampling t-test results can be seen in the Table above. Double-sided credit margins, $t$ statistics and meaningfulness value of the $t$ statistics are demonstrated at a significance level of $5 \%$ for the difference between averages, standard deviation of the differences and average differences. According to it, the meaningfulness value obtained for test statistics was calculated as $0,526>0,05$. According to the meaningfulness value, no meaningful difference was found between the average expenditures of 2008-2009 and 20092010 seasons at a significance level of $5 \%$.

\section{ANALYSIS OF THE INCOMES OF FOUR MAJOR CLUBS}

It will be examined whether there was a change between the incomes of the four major clubs in 2010-2011 season. For that purpose, following income items will be used as observation values:

- Match Day Incomes

- Broadcast Incomes

- Commercial Incomes

- Financial Incomes

Firstly, it will be analyzed whether the incomes of the four major clubs in 2010-2011 season demonstrate a normal distribution or not.

Tests of Normality

\begin{tabular}{|c|c|c|c|c|c|c|c|}
\hline & \multirow[b]{2}{*}{ Club } & \multicolumn{3}{|c|}{ Kolmogorov-Smirnov ${ }^{a}$} & \multicolumn{3}{|c|}{ Shapiro-Wilk } \\
\hline & & Statistic & df & Sig. & Statistic & df & Sig. \\
\hline \multirow[t]{4}{*}{ Income } & Galatasaray &, 214 & 4 & &, 963 & 4 & .795 \\
\hline & Fenerbahçe & ,308 & 4 & . &, 918 & 4 &, 525 \\
\hline & Beşiktaş &, 287 & 4 & . &, 870 & 4 &, 298 \\
\hline & Trabzonspor & ,394 & 4 & &, 743 & 4 &, 033 \\
\hline
\end{tabular}


10 I P a g e International Journal of Management Sciences and Business Research, 2012, Vol. 1, Issue 7. (ISSN:

Tests of Normality

\begin{tabular}{|c|c|c|c|c|c|c|c|}
\hline & \multirow[b]{2}{*}{ Club } & \multicolumn{3}{|c|}{ Kolmogorov-Smirnov ${ }^{a}$} & \multicolumn{3}{|c|}{ Shapiro-Wilk } \\
\hline & & Statistic & $d f$ & Sig. & Statistic & df & Sig. \\
\hline \multirow{4}{*}{ Income } & Galatasaray & 214 & 4 & & .963 & 4 & 795 \\
\hline & Fenerbahçe & ,308 & 4 & & ,918 & 4 &, 525 \\
\hline & Beşiktaş &, 287 & 4 & & 870 & 4 & ,298 \\
\hline & Trabzonspor & ,394 & 4 & & ,743 & 4 &, 033 \\
\hline
\end{tabular}

a. Lilliefors Significance Correction

Normality test results can be seen in the Table above. The number of observations is lower than 50 for the incomes of the four major clubs in 2010-2011 season, and therefore, Shapiro-Wilk test is applied. According to test results, meaningfulness value for Trabzonspor was calculated as $0,033<0,05$. The meaningfulness value for the other major clubs was calculated as higher than 0,05. So, it is the case that the incomes of Trabzonspor do not demonstrate a normal distribution at a significance level of $5 \%$.

\section{KRUSKAL-WALLIS TEST}

Since the data do not demonstrate a normal distribution, Kruskal-Wallis test was applied to compare the incomes of the four major clubs.

Ranks
\begin{tabular}{|ll|l|l|}
\hline Club & N & Mean Rank \\
\hline Income & Galatasaray & 4 & 8,00 \\
& Fenerbahçe & 4 & 9,75 \\
& Beşiktaş & 4 & 9,50 \\
& Trabzonspor & 4 & 6,75 \\
Total & 16 & \\
\hline
\end{tabular}

Order averages for the incomes of the four major clubs can be seen in the Table above.

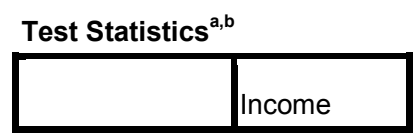

AN ANALYSIS ON THE INCOMES AND EXPENDITURES OF TURKISH EOOTBALL FEDERATION AND THE INCOMES OF THE FOUR MAJOR 
11 | P a g e International Journal of Management Sciences and Business Research, 2012, Vol. 1, Issue 7. (ISSN: 2226-8235)

\begin{tabular}{|l|l|}
\hline Chi-Square & 1,037 \\
df & 3 \\
Asymp. Sig. &, 792 \\
\hline
\end{tabular}

a. Kruskal Wallis Test

b. Grouping Variable: Club

Kruskal-Wallis test results can be seen in the Table above. According to test results, quisquare test statistics was calculated as 1,037 and meaningfulness value of the test statistics as 0,792. According to it, no meaningful difference was found between the average incomes of the four major clubs at a significance level of 5\%.

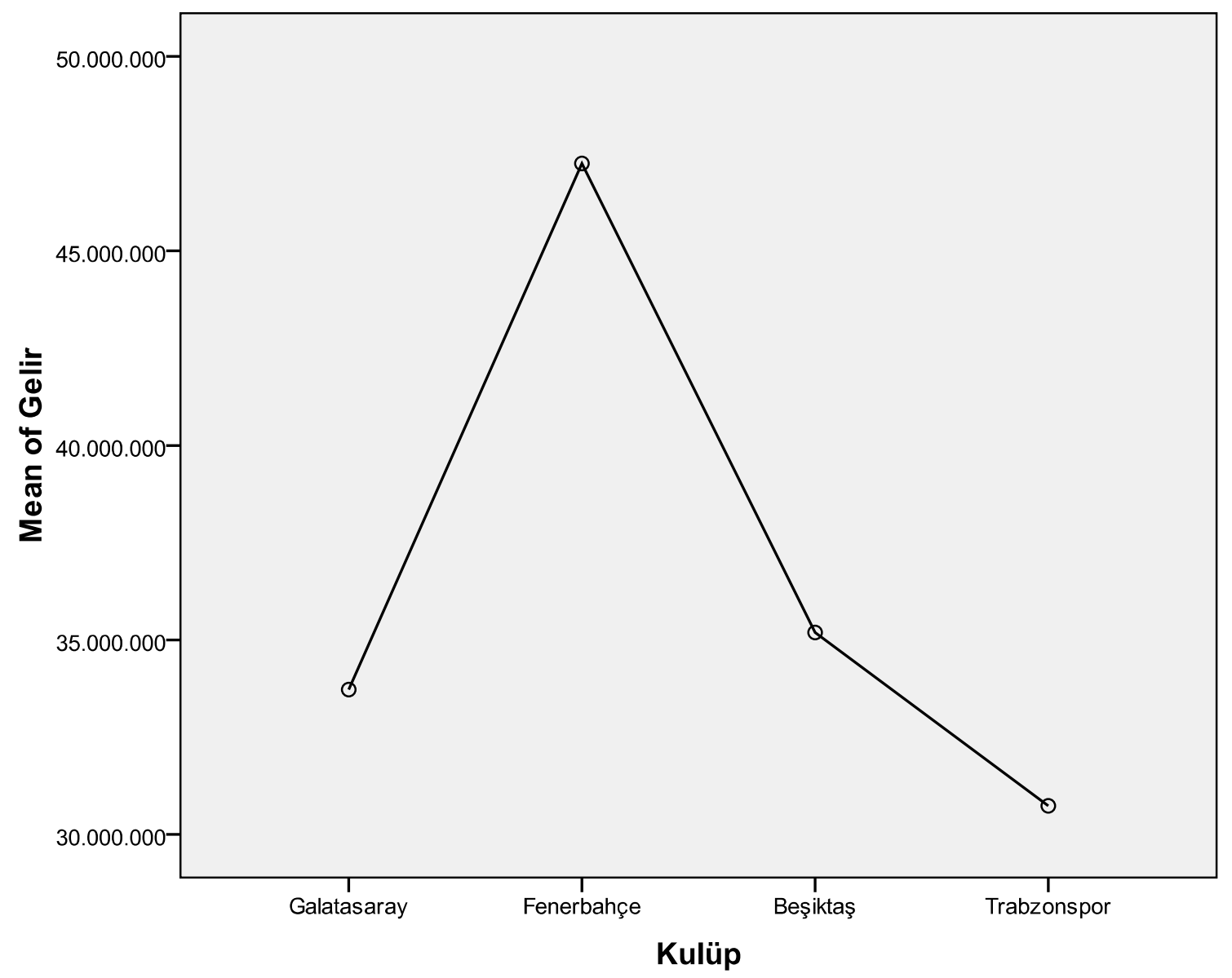


12 | P a g e International Journal of Management Sciences and Business Research, 2012, Vol. 1, Issue 7. (ISSN: 2226-8235)

Average incomes of the four major clubs for four income items can be seen in the Table above. According to the graphic, although there is no quantitative difference between the incomes of the clubs, this difference is not statistically meaningful.

\section{CONCLUSION AND ASSESSMENT}

In this study, it was focused on the incomes and expenditures of Turkish Football Federation (TFF) as well as sports clubs called four majors in Turkish public, and the financial structure of TFF as well as Beşiktaş, Fenerbahçe, Galatasaray and Trabzonspor was analyzed.

Certain income and expenditure items of 2008-2009 and 2009-2010 football seasons were used as data for TFF. Firstly, it was focused on whether there was a change between the average incomes of 2008-2009 and 2009-2010 seasons. A normality test was made for income items, and Wilcoxon test was applied due to the fact that data did not demonstrate a normal distribution. As a result of the test, it was found that there was not a meaningful difference between the average incomes of 2008-2009 and 2009-2010 seasons. In that case, it can be concluded that there is no meaningful improvement in TFF income and that the income situation follows a stable course.

On the other side of the study, it was examined whether there was a change between TFF's average expenditures of 2008-2009 and 2009-2010 seasons. The same normality test was also made for expenditure items, and paired t-test was applied due to the fact that data demonstrated a normal distribution. As a result of the test, it was found that there was not a meaningful difference between the average expenditures of 2008-2009 and 2009-2010 seasons. Thus, it can be said that there is no meaningful increase in the expenditure level of TFF.

In the final part of the study, it was examined whether there was a change between the average incomes of the four major Turkish clubs in the 2010-2011 football season. Several income items were used as data for that purpose. A normality test was applied for the income items, and it was found that data did not demonstrate a normal distribution. In that case, Kruskal-Wallis test was applied to determine whether there was a change between the average incomes of the four major Turkish clubs in the 2010-2011 football season. As a result of the Kruskal-Wallis test, no difference was found between the average incomes of the four major clubs in 2010-2011 season. Also, a graphical demonstration was presented for income levels. Considering the graphic, numerical differences can be seen between the income levels of the four major clubs, but these differences are not statistically meaningful. In this case, it can be concluded that the four major clubs are, on average, at the same income level for 2010-2011 season. 


\section{REFERENCES}

- Akaya, C., (2008). Küreselleşme ve Futboldaki Dönüşüm (Globalizing and Transformation in Football, Ethos: Felsefe ve Toplumsal Bilimlerde Diyaloglar (Philosophy and Dialogues in Social Sciences) July No: 1/4.

- Akşar, T., and Merih, K.., (2006). Futbol Ekonomisi (Football Economy), Istanbul.

- Akşar, T., (2008a). Taraftar mı? Müşteri mi? (Fan or Customer?), iletişim kuram ve araştırma dergisi (Communication and Research Journal), No 26 Winter-Spring 2008, p.347-352.

- Akşar, T., (2008b). Futbol Yönetimi (Football Management), Istanbul.

- Akşar, T., (2010). Futbolun Ekonomi Politiği (Economy Politics of Football), Istanbul.

- Arık, M.B., (2008), Futbol ve televizyon bağı: Simbiyoz beslenme (Football and television link: Symbiosis Nutrition), iletişim kuram ve Araştırma dergisi (Communication and Research Journal), No 26 Winter-Spring 2008, p.197-222.

- Deloitte, (2012). Edited by Dan Jones, Fan Power Football Money League, Sports Business Group, February 2012.

- Demir, V., (1998). Türkiye'de Futbol Maçlarının Yayın Hakkı Sorunu (The Issue of Broadcast Right of Football Matches in Turkey), İstanbul Üniversitesi Illetişim Fakültesi Hakemli Dergisi (Refereed Journal Istanbul University Communication Faculty), No 8.

- Devecioğlu, S., (2003) Gazi Beden Eğitimi ve Spor Bilimleri Dergisi (Gazi Physical Education and Sports Sciences Journal), Volume:VIII, No:3, p.49-58.

- Devecioglu, S., Çoban, B., Türkiye'de Profesyonel Futbolun Finansı (Professional Football Finance in Turkey), Spor Araştırmaları Dergisi (Sports Research Journal), Volume:7, No:3 December 2003.

- Doğru, C., (2010). Futbol Endüstrisinde Rekabetçi Dengenin Oluşturulmasına Matematiksel Bir Yaklaşım: Ücret Tavanı Modeli 1 (A Mathematical Approach to Establishing a Competitive Balance in Football Industry: Fee Ceiling Model 1), Uluslar arası Iiktisadi ve İdari incelemeler Dergisi (International Journal of the School of Economics and Administrative Sciences), Year:2 Volume:2 No:4, Winter 2010 ISSN 1307-9832.

- İnan, T., (2007). Türkiye'deki Futbol Kulüplerinin Gişe Gelirini Arttırmaya Yönelik Uygulamaların Incelenmesi (Analyzing the Practices for Increasing the Box-Office Incomes of Football Clubs in Turkey), Doctoral Thesis, Çukurova University, Graduate School of Health Sciences, Adana.

- Katırcı, H. \& Uztuğ, F., (2009). Spor Kulüplerinde İletişim Yönetimi: Türkiye Profesyonel Futbol Liglerinde Yer Alan Spor Kulüplerinin Iletişim Uygulamalarına İlişkin Araştırma (Communication Management in Sports Clubs: A Research on Communication Practices of Sports Clubs in Professional Football Leagues of Turkey), Anadolu University Journal of Social Sciences Vol.:9 - No: 1 : 149-168 (2009) 
14 | P a g e International Journal of Management Sciences and Business Research, 2012, Vol. 1, Issue 7. (ISSN:

- Orta, L., (2008). Futbol Oyun Kurallarının Evrimi (Evolution of Football Playing Rules) (1863-2008), iletişim Kuram ve Araştırma Dergisi (Journal of Communication Rules and Research), No 26 Winter-Spring 2008, p.461-476.

- TFF Law No:5894, Türkiye Futbol Federasyonu Kuruluş Ve Görevleri Hakkında Kanun (Law on Turkish Football Federation Foundation and Tasks), Accepted on: $5 / 5 / 2009$.

- TFF, (2009). 2008- 2009 Financial Tables.

- TFF, (2010a). 2009- 2010 Financial Tables.

- Akşar, T., (2011a). Süper Lig'de Havuz Gelirleri Yeniden Düzenlenmelidir (Pool Incomes in the Super League should be re-regulated), http://www.futbolekonomi.com/index.php?option=com content\&view=articl e\&id=1542

- Akşar, T., (2011b). Şampiyonluğu Kazanan Milyonları da Kazanıyor (The One Winning the Championship is Also the Winner of Millions),

http://www.futbolekonomi.com/index.php?option=com content\&view=articl e\&id=1532

- TFF, (2010b), Balance Sheet of the 31 May 2010

Period,http://www.tff.org/Resources/TFF/Documents/002011/TFF/1-06-

2009-31-5-2010-Donemi-Gelir-Gider-Tablesu.pdf 